Shigeki Yamaguchi MD,

Shinsuke Hamaguchi MD, Mutsuo Mishio MD, Yasuhisa Okuda MD, Toshimitsu Kitajima MD

\title{
Propofol prevents lipid peroxidation following transient forebrain ischemia in gerbils
}

Purpose: To ascertain whether propofol prevents lipid peroxidation on delayed neuronal death induced by transient forebrain ischemia in the hippocampal CAI subfield in gerbils.

Methods: Forty gerbils were randomly assigned to five groups: Group I, control, sham operation treated with physiological saline solution (PSS); Group II, ischemia/reperfusion treated with PSS; Group III, ischemia/reperfusion treated with $50 \mathrm{mg} \cdot \mathrm{kg}^{-1}$ propofol; Group IV, ischemia/reperfusion treated with $100 \mathrm{mg} \cdot \mathrm{kg}^{-1}$ propofol; Group $\mathrm{V}$, ischemia /reperfusion treated with $150 \mathrm{mg} \cdot \mathrm{kg}^{-1}$ propofol. Transient forebrain ischemia was induced by occluding the bilateral common carotid arteries for four minutes under $\mathrm{N}_{2} \mathrm{O} / \mathrm{O}_{2}$ /halothane anesthesia after propofol or PSS. Five days later, the cerebrum was removed and each forebrain was cut into two including the hippocampus. Lipid peroxidation was determined using the production of malondialdehyde (MDA), and histopathological changes in the hippocampal CAI subfield were examined.

Results: In group II, the pyramidal cells were atrophic and pycnotic; vacuolation and structural disruption of the radial striated zone was observed. In the other four groups, these changes were not observed. Degenerative ratios of pyramidal cells were: Group I: $4.9 \pm 2.3$, Group II: $94.1 \pm 4.5(P<0.0$ I), Group III: $12.5 \pm 5.7$, Group IV: I I.0 \pm 4.6, Group V: $9.6 \pm 4.9 \%$. Production of MDA was: Group I: $83 \pm 22$, Group II: $198 \pm 25$ $\left(P<0.0\right.$ I), Group III: $153 \pm 39$, Group IV: I $13 \pm 34$, Group V: I $06 \pm 27 \mathrm{nmol} \cdot \mathrm{g}^{-1}$ wet tissue.

Conclusion: Propofol attenuated delayed neuronal death by preventing lipid peroxidation induced by transient forebrain ischemia in the hippocampal CAI subfield in gerbils.

Objectif : Vérifier si le propofol empêche la peroxydation lipidique qui survient à la mort neuronale différée induite par une ischémie transitoire du prosencéphale, dans le sous-champ CAI de l'hippocampe chez des gerbilles.

Méthode : On a réparti au hasard 40 gerbilles en cinq groupes : dans le groupe I, témoin, elles ont subi une opération fictive traitée avec une solution physiologique salée (SPS); dans le groupe II, une ischémie/reperfusion traitée avec une SPS; dans le groupe III, une ischémie/reperfusion traitée avec $50 \mathrm{mg} \cdot \mathrm{kg}^{-1}$ de propofol; dans le groupe IV, une ischémie/reperfusion traitée avec $100 \mathrm{mg} \cdot \mathrm{kg}^{-1}$ de propofol et dans le groupe $\mathrm{V}$, une ischémie/reperfusion traitée avec $150 \mathrm{mg} \cdot \mathrm{kg}^{\mid}$de propofol. L'ischémie transitoire du cerveau antérieur a été induite par l'occlusion bilatérale des artères carotides communes pendant quatre minutes sous anesthésie au $\mathrm{N}_{2} \mathrm{O} / \mathrm{O}_{2}$ /halothane après l'administration de propofol ou de SPS. Cinq minutes plus tard, le cerveau a été retiré et chaque prosencéphale a été coupé en deux, incluant l'hippocampe. La peroxydation lipidique a été déterminée en utilisant la production de malondialdéhyde (MDA), et les changements histopathologiques du sous-champ CAI de l'hippocampe ont été examinés.

Résultats : Dans le groupe II, les cellules pyramidales étaient atrophiques et pycnotiques; une rupture vacuolaire et structurale de la zone radiale striée a été observée. Dans les autres groupes, ces changements n'ont pas été notés. Les taux de cellules pyramidales dégénératives ont été : groupe I : 5,8 $\pm 2,5 \%$, groupe $\mid I: 94,1 \pm 4,5$ $(P<0,0 \mid)$, groupe III : I2,5 $\pm 5,7 \%$, groupe IV : II,0 $\pm 4,6 \%$, groupe $V: 9,4 \pm 6,6 \%$. La production de MDA a été dans le groupe I : $83 \pm 22$, II : I $98 \pm 25(P<0,0$ I $)$, III : I $53 \pm 39$, IV : I I3 \pm 34 et V : I06 \pm 27 $\mathrm{nmol} \cdot \mathrm{g}^{-1}$ de tissu.

Conclusion : Le propofol a réduit la mort neuronale différée en empêchant la peroxydation lipidique induite par l'ischémie transitoire du prosencéphale dans le sous-champ CAI de l'hippocampe de gerbilles.

From the Department of Anesthesiology, Dokkyo University School of Medicine, Mibu, Tochigi 321-0293, Japan.

Address correspondence to: Shigeki Yamaguchi MD. Phone: 81-282-86111l, Ext. 3802; Fax: 81-282-860478; E-mail: sigeki@peach.ocn.ne.jp Accepted for publication July 8, 2000. 
A few clinical reports suggest that propofol may benefit patients with severe head injury, ${ }^{1,2}$ because it reduces cerebral metabolic rate, ${ }^{3,4}$ cerebral blood flow, ${ }^{4,5}$ and intracranial pressure. . $^{1,2,6}$

Therefore, propofol has increasingly been used for the maintenance of neurosurgical anesthesia and sedation for head-injured patients. Also, several studies have reported that propofol improved neurological outcome and decreased neuronal damage in vivo. ${ }^{7,8} \mathrm{We}$ have shown that propofol reduces neuronal damage following transient forebrain ischemia using the model of delayed neuronal death developed by Kirino. ${ }^{9,10}$ The neuronal protective property of anesthetics has been frequently attributed to their ability to reduce cerebral metabolism and to suppress brain electrical activity. However, recent reports suggest that cerebral metabolic reduction is not sufficient to provide neuronal protection and that alternative mechanisms supporting this effect could be related to the cascade of biochemical events triggered by ischemia/reperfusion. ${ }^{11}$ However, the mechanism remains to be established. Propofol has antioxidant actions and reduces oxidative stress. ${ }^{12-21}$ Since propofol attenuates oxidative stress, propofol may prevent lipid peroxidation following ischemia/reperfusion in the brain. Therefore, we designed the present study using delayed neuronal death after transient forebrain ischemia in gerbils to ascertain whether propofol may prevent lipid peroxidation in the hippocampal CAl subfield.

\section{Methods}

The study was conducted according to the animal experimentation guidelines of Dokkyo University School of Medicine, which adhere to the National Institute of Health Animal Experimental Guidelines.

\section{Experimental protocol}

Forty Mongolian gerbils weighing between 75-95 g were divided into the following five groups.

Group I: $15 \mathrm{ml} \cdot \mathrm{kg}^{-1}$ physiological saline solution (PSS) were administered ip $30 \mathrm{~min}$ before a sham operation $(\mathrm{n}=8)$.

Group II: $15 \mathrm{ml} \cdot \mathrm{kg}^{-1}$ PSS were administered ip 30 min before ischemia/reperfusion $(n=8)$.

Group III: $50 \mathrm{mg} \cdot \mathrm{kg}^{-1}$ propofol with $10 \mathrm{ml} \cdot \mathrm{kg}^{-1}$ PSS were administered ip $30 \mathrm{~min}$ before ischemia/reperfusion $(\mathrm{n}=8)$.

Group IV: $100 \mathrm{mg} \cdot \mathrm{kg}^{-1}$ propofol with $5 \mathrm{ml} \cdot \mathrm{kg}^{-1}$ PSS were administered ip $30 \mathrm{~min}$ before ischemia/reperfusion $(n=8)$.

Group V: $150 \mathrm{mg} \cdot \mathrm{kg}^{-1}$ propofol were administered ip $30 \mathrm{~min}$ before ischemia/reperfusion $(\mathrm{n}=8)$.
After ether induction of anesthesia in a glass cage, a rubber bag was placed over the head of each gerbil and nitrous oxide $50 \%$ in oxygen with halothane (end-tidal concentration: $1.0-1.5 \%$ ) was administered throughout the procedure. The animals were then placed in the supine position and the common carotid arteries were exposed bilaterally. In group I, no further procedures were performed. In groups II through V, the common carotid arteries were occluded with miniature aneurysmal clips for four minutes. During this period, the absence of blood supply from the vertebral arteries was verified microscopically. Four minutes after bilateral carotid artery occlusion, the clips were released and spontaneous reperfusion was confirmed with the microscope. The temperature of the tympanic membrane was monitored (Mon-a-therm Model 6510 ; Mallinckrodt) and maintained with a heating blanket at $37 \pm 0.2^{\circ} \mathrm{C}$ during the experiment.

Respiration of the animals, by visual inspection, was temporarily shallow during the procedure but this improved after reperfusion. The animals were kept and fed in the cage at $26^{\circ} \mathrm{C}$. Five days later, each gerbil was decapitated under ether anesthesia and the forebrain was removed within two minutes. Each forebrain was cut into two portions including the hippocampus in the coronal direction: in one portion we assessed lipid peroxidation, and in the other we examined histopathological changes in the hippocampal CAl subfield.

\section{Assessment of lipid peroxidation}

Lipid peroxidation in the first portion of the forebrain was determined according to the method of Ohkawa et al. ${ }^{2}$ and its level was expressed as nanomoles of malondialdehyde (MDA) per gram of wet tissue.

\section{Examination of histopathological changes}

The second portion of the forebrain was fixed by solution, containing formaldehyde $4 \%$, phosphate buffer solution and distilled water in a ratio of $1: 2: 7$, and embedded in paraffin, then sliced into $5 \mu \mathrm{m}$ sections in the coronal direction and stained with hematoxylin and eosin. Histopathological changes in the hippocampal CAl subfield were examined using a light microscope (Olympus BH-2, Olympus, Japan). Morphological changes were detected in the pyramidal cells and structural changes in the cell layers of the CAl subfield of the hippocampus. In order to compare the ratios of degenerative pyramidal cells among the five groups, the total number and the degenerative number of pyramidal cells were counted for a uniform $1 \mathrm{~mm}$ length of the central area of the hippocampal CAl subfield. The degenerative ratios were determined according to the 
TABLE I Production of malondialdehyde.

\begin{tabular}{lll}
\hline Group & $\begin{array}{l}\text { malondialdehyde } \\
(\text { nmol.g }\end{array}$ \\
\hline I & $\begin{array}{l}\text { Sham operation, saline-treated } \\
\text { II }\end{array}$ & $\begin{array}{l}\text { Ischemia-reperfusion, saline-treated } \\
\text { Is }\end{array}$ \\
III & $\begin{array}{l}\text { Ischemia-reperfusion, propofol } \\
\left(50 \mathrm{mg} \cdot \mathrm{kg}^{-1}\right) \text { treated }\end{array}$ & $153 \pm 39$ \\
IV & $\begin{array}{l}\text { Ischemia-reperfusion, propofol } \\
\left(100 \mathrm{mg} \cdot \mathrm{kg}^{-1}\right) \text { treated }\end{array}$ & $113 \pm 34 \dagger$ \\
$\mathrm{V}$ & $\begin{array}{l}\text { Ischemia-reperfusion, propofol } \\
\left(150 \mathrm{mg} \cdot \mathrm{kg}^{-1}\right) \text { treated }\end{array}$ & $106 \pm 27 \dagger$ \\
\hline
\end{tabular}

* $P<0.01$ vs groups I, III, IV and V.

$\dagger P<0.05$ vs group III.

Values are mean \pm SD.

TABLE II Cell degenerative ratio.

\begin{tabular}{lll}
\hline Group & $\begin{array}{l}\text { Degenerative ratio } \\
(\%)\end{array}$ \\
\hline I & Sham operation, saline-treated & $4.9 \pm 2.3$ \\
II & Ischemia-reperfusion, saline-treated & $94.1 \pm 4.5^{*}$ \\
III & $\begin{array}{l}\text { Ischemia-reperfusion, propofol } \\
\left(50 \mathrm{mg}^{-1} \mathrm{~kg}^{-1}\right) \text { treated }\end{array}$ & $12.5 \pm 5.7$ \\
IV & $\begin{array}{l}\text { Ischemia-reperfusion, propofol } \\
\left(100 \mathrm{mg} \cdot \mathrm{kg}^{-1}\right) \text { treated }\end{array}$ & $11.0 \pm 4.6$ \\
V & $\begin{array}{l}\text { Ischemia-reperfusion, propofol } \\
\left(150 \mathrm{mg} \cdot \mathrm{kg}^{-1}\right) \text { treated }\end{array}$ & $9.6 \pm 4.9$ \\
\hline
\end{tabular}

${ }^{*} P<0.01$ vs other groups I, III, IV, V . Values are mean \pm SD. Degenerative ratio $(\%)=($ number of degenerative pyramidal cells)/(total number of pyramidal cells per $1 \mathrm{~mm}$ hippocampal CAl subfield $) \times 100$.

following formula: degenerative ratio $(\%)=$ (number of degenerative pyramidal cells/total number of pyramidal cells per $1 \mathrm{~mm}$ of hippocampal CAl subfield) $\times 100$.

Signs of degenerative processes such as atrophy of the pyramidal cells, deep staining of their cell bodies, vacuolation, and disappearance of the radial striated zone were taken to indicate cell degeneration, and cells in which these signs were absent were regarded as normal neurons. ${ }^{14,15}$

\section{Statistical analysis}

Data are presented as mean \pm SD. Kruskall-Wallis oneway analysis of variance was used for the statistical comparisons between each group. Statistical significance was considered to be $P<0.05$.

Results

\section{Assessment of lipid peroxidation}

The production of MDA in group I was $83 \pm 22$ $\mathrm{nmol} \cdot \mathrm{g}^{-1}$ wet tissue. In group II, however, it was $198 \pm$ $25 \mathrm{nmol} \cdot \mathrm{g}^{-1}$ wet tissue and higher than in group I $(P<$
$0.01)$. The MDA in groups III, IV and V were $153 \pm$ $39,113 \pm 34$ and $106 \pm 27 \mathrm{nmol} \cdot \mathrm{g}^{-1}$ wet tissue, respectively. These values were lower than in group II. The production of MDA in group III was higher than in group IV $(P<0.05)$ and $\mathrm{V}(P<0.01)$. The production of MDA after ischemia/reperfusion was prevented by propofol, and incremental doses of propofol produced weak to strong antioxidant action. (Table I)

\section{Histopathological findings}

In group I, normal pyramidal cells were well preserved and no disruption of the radial striated zone was detected. In group II, however, almost all the pyramidal cells were atrophic and pycnotic, and they exhibited deep staining of the cell cytoplasm, vacuolation, as well as structural disruption of the radial striated zone due to degenerative necrosis. In groups III, IV and V, the pyramidal cells of the hippocampal CAl subfield were maintained as morphologically normal structures and no structural disruption was observed in the radial striated zones. (Figure 1 )

\section{Cell degenerative ratios}

The degenerative ratios of each group are shown in Table II. The degenerative ratio in group I was $4.9 \pm$ $2.3 \%$ and was the lowest among the other groups. In group II, however, it was $94.1 \pm 4.5 \%(P<0.01$ vs group I). The degenerative ratio in groups III, IV and $\mathrm{V}$ was lower than that in group II. There were no significant differences among groups III, IV and V. The administration of propofol before ischemia/reperfusion produced an inhibitory action on delayed neuronal death. In this study, the neuronal protective effects of propofol were not dose-dependent.

\section{Discussion}

Five days after forebrain ischemia, lipid peroxidation and histopathological changes were observed simultaneously. The administration of propofol before transient forebrain ischemia prevented degeneration in hippocampal CAl pyramidal cells. This suggests that anti-peroxidation may play an important role in the neuronal protective properties after ischemia/reperfusion.

A short period of ischemia/reperfusion induces a selective death which is called delayed neuronal death in the pyramidal cells of hippocampal CAl.${ }^{9}$ There was no histopathological change in the pyramidal cells on the first or second day after cerebral ischemia/reperfusion, and they became degenerative on the third or fourth day. Since delayed neuronal death caused by a short period of ischemia/ reperfusion was similar to that observed in humans, ${ }^{23,24}$ this model has been widely used for cerebral ischemia and infraction. The mecha- 


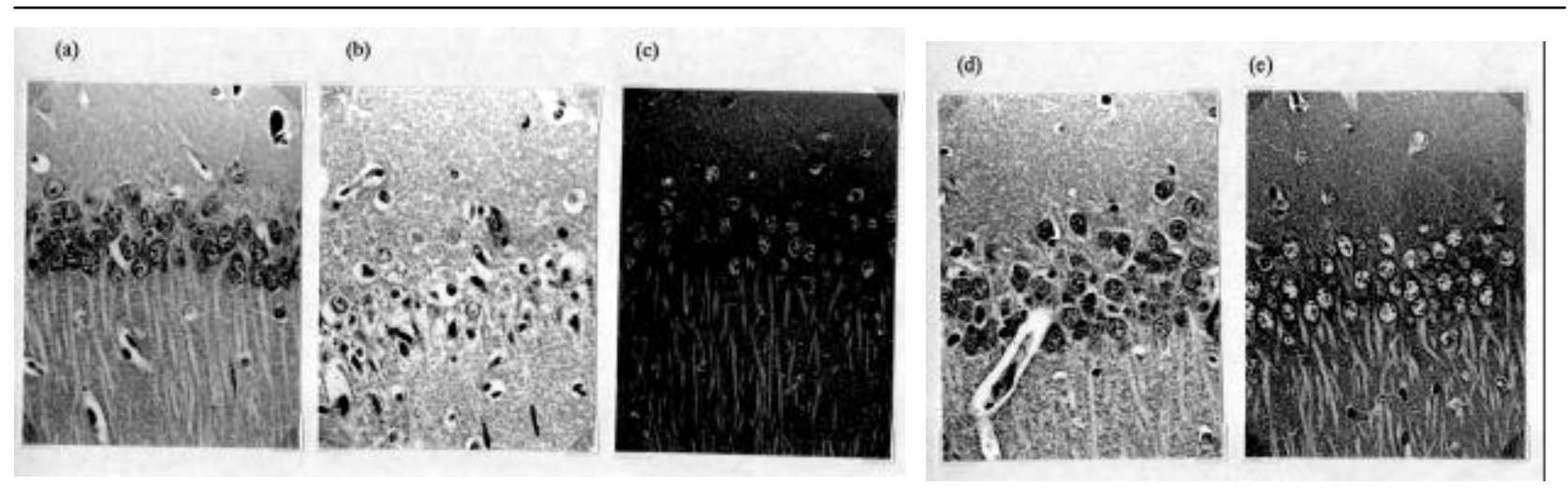

FIGURE I(a) - (e) The histological pictures of hippocampal CAl from each group. (a) group I; normality of the CAl pyramidal cells was well preserved. (b) group II; changes of the CAl pyramidal cells were present: cell shrinkage, nuclear pycnosis, dark cytoplasmic colouration and vacuolation. (c) groups III, IV and V; normality of the CAl pyramidal cells was well preserved.

nisms of delayed neuronal death after a short period of ischemia/reperfusion are unclear and continue to be discussed. In some reports, it was considered as programmed cell death such as apoptosis. ${ }^{25-28}$

We reported that the generation of free radicals may play an important role in delayed neuronal death. ${ }^{29}$ The generation of free radicals is considered to be dependent on an abnormal electron transport system of mitochondria, an abnormal hypoxanthine-xanthine oxidase system and activated neutrophils. ${ }^{29-33}$ Furthermore, the increase in neuronal damage induced by free radicals is usually accompanied by disturbance of antioxidant defenses. ${ }^{21}$ The generation of free radicals derived from oxygen after ischemia/reperfusion, which leads to the production of lipid peroxides in cell membranes, is one of the major mechanisms of tissue damage in ischemia/reperfusion. ${ }^{30-33}$

Propofol has antioxidant properties and prevents lipid peroxidation ${ }^{12-21}$ and has been reported to enhance tissue antioxidant capacity clinically in a few studies. ${ }^{13,14,16}$ Propofol is similar in chemical structure to the active nucleus of the endogenous antioxidant tocopherol and butylhydroxytoluene. ${ }^{15,17}$ These molecules bind to cell membranes or to phospholipids to form free radicals, and terminate lipid peroxidation by reacting with lipid peroxyl radicals to form the nonreactive phenoxyl radical. Propofol may act through a similar mechanism when it is administered prior to insult. Its antioxidant effect results from the inhibition of lipid peroxidation by the formation of relatively low reactive free radicals that disrupt the chain of formation of other radicals potentially being able to cause greater damage to cell membranes. ${ }^{34}$
In the present study, we examined the histopathological changes and product of MDA in the hippocampal CAl subfield five days after ischemia/reperfusion. Degeneration of hippocampal CAl pyramidal cells and a product of MDA in the forebrain were observed simultaneously in gerbils which received PSS. Toxic metabolites of MDA are produced by lipid preoxidation and may be evaluated as a simple and sensitive assay of lipid peroxidation for application to laboratory and clinical study. ${ }^{2}$ The tissue level of MDA indicates the presence of oxidant mediated injury, in response to the condition of ischemia/reperfusion. These results suggest that lipid peroxidation induced by free radicals may cause delayed neuronal death after transient forebrain ischemia. Then, propofol may attenuate the degeneration of hippocampus CAl pyramidal cells and prevent lipid peroxidation. In all gerbils that received propofol, the similar effects of propofol on cell degeneration were observed without dose-dependence. Although the grades of sedation for each group were not shown in the present study, we reported that 50 to $150 \mathrm{mg} \cdot \mathrm{kg}^{-1}$ propofol appeared to produce mild sedation to deep anesthesia in our previous study. ${ }^{10}$ It is suggested that a small dose of propofol might depress delayed neuronal death. On the other hand, incremental doses of propofol produced weak to strong antioxidant action. The administration of a dose of propofol that provides deep anesthesia may produce a strong antioxidant action, followed by attenuation of the neuronal damage. Some clinical reports also showed that propofol prevented the production of MDA and acts as an antioxidant. ${ }^{13,14}$ These results suggest that propofol may protect neuronal damage which is induced by oxidative stress after 
ischemia/reperfusion such as unexpected cardiac arrest during anesthesia.

In conclusion, administration of propofol prevented lipid peroxidation and delayed neuronal death after transient forebrain ischemia. These results suggest that propofol may play an antioxidant during the oxidative stress.

\section{References}

1 Pinaud M, Lelausque J-N, Chetanneau A, Fauchoux N, Ménégalli D, Souron $R$ Effects of propofol on cerebral hemodynamics and metabolism in patients with brain trauma. Anesthesiology 1990; 73: 404-9.

2 Kelly DF, Goodale DB, Williams J, et al. Propofol in the treatment of moderate and severe head injury: a ramdomized, prospective double-blinded pilot trial. J Neurosurg 1999; 90: 1042-52.

3 Sebel PS, Lowdon JD. Propofol: a new intravenous anesthetic. Anesthesiology 1989; 71: 260-77.

4 Vandesteene A, Trempont V, Engelman E, et al. Effect of propofol on cerebral blood flow and metabolism in man. Anaesthesia 1988; 43(Suppl): 42-3.

5 Van Hemelrijck J, Fitch W, Mattheussen M, Van Aken $H$, Plets $C$, Lauwers T. Effect of propofol on cerebral circulation and autoregulation in the baboon. Anesth Analg 1990; 71: 49-54.

6 Ravussin P, Guinard JP, Ralley F, Thorin D. Effect of propofol on cerebrospinal fluid pressure and cerebral perfusion pressure in patients undergoing craniotomy. Anaesthesia 1988; 43(Suppl): 37-41.

7 Kochs E, Hoffman WE, Werner C, Thomas C, Albrecht $R F$, Schulte am Esch J. The effects of propofol on brain electrical activity, neurologic outcome, and neuronal damage following incomplete ischemia in rats. Anesthesiology 1992; 76: 245-52.

8 Arcadi FA, Rapisarda A, De Luca R, Trimarchi GR, Costa $G$ Effect of 2,6-diisopropylphenol on the delayed hippocampal cell loss following transient forebrain ischemia in the gerbil. Life Sci 1996; 58: 961-70.

9 Kirino T. Delayed neuronal death in the gerbil hippocampus following ischemia. Brain Res 1982; 239: 57-69.

10 Yamaguchi S, Midorikawa $\Upsilon$, Okuda $\Upsilon$, Kitajima $T$. Propofol prevents delayed neuronal death following transient forebrain ischemia in gerbils. Can J Anesth 1999; 46: 593-8.

11 Todd M, Warner DS. A comfortable hypothesis reevaluated. Cerebral metabolic depression and brain protection during eschemia (Editorial). Anesthesiology 1992; 76: 161-4.

12 Sitar SM, Hanifi-Moghaddam P, Gelb A, Cechetto DF, Siushansian R, Wilson JX. Propofol prevents peroxideinduced inhibition of glutamate transport in cultured astrocytes. Anesthesiology 1999; 90: 1446-53.

13 Ansley DM, Sun J, Visser WA, et al. High dose propofol enhances red cell antioxidant capacity during CPB in humans. Can J Anesth 1999; 46: 641-8.

14 Ansley DM, Lee J, Godin DV, Garnett ME, Qayumi AK. Propofol enhances red cell antioxidant capacity in swine and humans. Can J Anaesth 1998; 45: 233-9.

15 Murphy PG, Myers DS, Davies MJ, Webster NR, Jones $J G$. The antioxidant potential of propofol $(2,6$-diisoprophylphenol) .Br J Anaesth 1992; 68: 613-8.

16 Hans $P$, Deby-Dupont $G$, Deby $C$, et al. Increase in antioxidant capacity of plasma during propofol anesthesia. J Neurosurg Anesth 1997; 9: 234-6.

17 Hans P, Deby C, Deby-Dupont G, Vrijens B, Albert A, Lamy $M$. Effect of propofol on in vitro lipid peroxidation induced by different free radical generating systems: a comparison with vitamin E. J Neurosurg Anesth 1996; 8: 154-8.

18 Monithys-Mickalad A, Hans P, Deby-Dupont G, Hoebeke $M$, Deby $C$, Lamy $M$ Propofol reacts with peroxynitrite to form a phenoxyl radical: demonstration by electron spin resonance. Biochem Biophy Res Com 1998; 249: 833-7.

19 De La Cruz JP, Zanca A, Carmona JA, Sánchez de la Cuesta $F$. The effect of propofol on oxidative stress in platelets from surgical patients. Anesth Analg 1999; 89: 1050-5.

20 De La Cruz JP, Sedeño G, Carmona JA, Sánchez de la Cuesta $F$. The in vitro effects of propofol on tissular oxidative stress in the rat. Anesth Analg 1998; 87: 1141-6.

21 De La Cruz JP, Villalobos MA, Sedeño G, Sánchez de la Cuesta $F$. Effect of propofol on oxidative stress in an in vitro model of anoxia-reoxygenation in the rat brain. Brain Res 1998; 800: 136-44.

22 Obkawa H, Obishi N, Yagi K. Assay for lipid peroxides in animal tissues by thiobarbituric acid reaction. Anal Biochem 1979; 95: 351-8.

23 Petito CK, Feldmann E, Pulsinelli WA, Plum F. Delayed hippocampal damage in humans following cardiorespiratory arrest. Neurology 1987; 37: 1281-6.

24 Horn M, Schlote W. Delayed neuronal death and delayed neuronal recovery in the human brain following global ischemia. Acta Neuropathol 1992; 85: 79-87.

25 Maeda M, Sugiyama T, Akai F, Jikihara I, Hayashi $\Upsilon$, Takagi $H$ Single stranded DNA as an immunocytochemical marker for apoptotic change of ischemia in the gerbil hippocampus. Neurosci Lett 1998; 240: 69-72.

26 Kinoshita M, Tomimoto H, Kinoshita A, Kumar S, Noda M. Up-regulation of the Nedd2 gene encoding an ICE/Ced-3-like cysteine protease in the gerbil brain after transient global ischemia. J Cereb Blood Flow Metab 1997; 17: 507-14. 
27 Nitatori T, Sato N, Waguri S, et al. Delayed neuronal death in the CAl pyramidal cell layer of the gerbil hippocampus following transient ischemia is apoptosis. J Neurosci 1995; 15: 1001-11.

28 Kihara S, Shiraishi T, Nakagawa S, Toda K, Tabuchi $K$ Visualization of DNA double strand breaks in the gerbil hippocampal CAl following transient ischemia. Neurosci Lett 1994; 175: 133-6.

29 Yamaguchi S, Ogata H, Hamaguchi S, Kitajima $T$. Superoxide radical generation and histopathological changes in hippocampal CAl after ischaemia/reperfusion in gerbils. Can J Anaesth 1998; 45: 226-32.

30 Hall ED. Free radicals and CNS injury. Crit Care Clin 1989; 5: 793-805.

31 Ikeda $\Upsilon$, Long DM. The molecular basis of brain injury and brain edema: the role of oxygen free radicals.

Neurosurgery 1990; 27: 1-11.

32 Siesjö BK, Agardh C-D, Bengtsson F. Free radicals and brain damage. Cerebrovascular and Brain Metabolism Reviews 1989; 1: 165-211.

33 Siesjö BK. Pathophysiology and treatment of focal cerebral ischemia. Part II: Mechanisms of damage and treatment. J Neurosurg 1992; 77: 337-54.

34 Hara H, Kato H, Kogure K Protective effect of $\alpha$-tocopherol on ischemic neuronal damage in the gerbil hippocampus. Brain Res 1990; 510: 335-8. 